Chirurgia (2020) 115: 511-519

No. 4, July - August

Copyright@ Celsius

http://dx.doi.org/10.21614/chirurgia.115.4.511

\title{
Breast Adenoid Cystic Carcinoma in a Patient in with Previous Contra-lateral Breast Ductal Carcinoma in-situ: A Case Report
}

\author{
Marina Barron', Amira Asaad², Kashuf Arooj Khan ${ }^{3}$, Philip Idaewor ${ }^{2}$, Ali Salih², Firas Alkistawi², Turhan Comez², \\ Victoria Salih ${ }^{4}$, Abdalla Saad Abdalla Al-Zawi ${ }^{2}$
}

'Department of Surgery, South West Acute Hospital, Enniskillen, Northern Ireland

2Department of Surgery, Basildon \& Thurrock University Hospital, Basildon, United Kingdom

${ }^{3}$ Department of Surgery, Royal Shrewsbury Hospital, Shrewsbury, United Kingdom

${ }^{4}$ Department of Surgery, King's College Hospital, London, United Kingdom

*Corresponding author:

Amira Asaad, MD

Department of Surgery

Basildon \& Thurrock University Hospital

Basildon, United Kingdom

E-mail: asaadamira89@gmail.com

\begin{abstract}
Rezumat
Carcinom chistic adenoid la sân la o pacientă cu antecedente de carcinom ductal mamar contralateral in situ: o prezentare de caz
\end{abstract}

Carcinomul chistic adenoid al sânului (BACC) este un neoplasm mamar malign rar întâlnit cu un rezultat favorabil, în ciuda statutului de receptor triplu negativ. Acesta cuprinde mai puțin de $0,1 \%$ din toate cazurile de cancer mamar. Situsul primar mai obişnuit al carcinomului chistic adenoid este observat în glandele salivare, cu toate acestea prognosticul BACC este mai bun decât cel pentru glanda salivară şi, de asemenea, cel al altor carcinomuri invazive mamare. De asemenea, este cunoscut ca BACC are mai puține metastaze ale ganglionilor limfatici, precum şi mai puține metastaze îndepărtate, prin acest caz prezentăm o femeie de 73 de ani cu antecedente de carcinom ductal mamar in situ, care apoi a dezvoltat carcinom chistic adenoid mamar contralateral.

Cuvinte cheie: cancer de sân, carcinom chistic adenoid de sân, cilindrom, cancer de sân triplu negativ

Abstract

Breast adenoid cystic carcinoma (BACC) is a rarely encountered malignant breast neoplasm with a favourable outcome, despite its triple-negative receptor status. It is comprising less than $0.1 \%$ of all 
breast cancers. The more usual primary site of the adenoid cystic carcinoma is seen in the salivary glands, however BACC prognosis is better than the one for salivary gland and also than that of other breast invasive carcinoma. BACC also known to have fewer lymph node metastases as well as fewer distant metastases, hereby we present 73 years old female with previous history of breast ductal carcinoma in-situ, then developed contralateral breast adenoid cystic carcinoma.

Key words: breast cancer, breast adenoid cystic carcinoma, cylindroma, triple negative breast cancer

\section{Introduction}

In addition to breast invasive ductal carcinoma, there are 18 different special and rare pathomorphologic subtypes of invasive breast cancer, one of these rarer breast cancers is breast adenoid cystic carcinoma (BACC), a salivary gland-type of breast carcinoma

It is uncommon to diagnose BACC as its incidence ranges between $0.1 \%$ to $1 \%$ of all breast cancers (1-3). Billroth in 1859 initially called this tumour called "cylindroma" or "cylindromatous adenocarcinoma ",due to its unique characteristic histologic appearance of dual populations of epitheloid cells and basaloid cells (Fig. 1), in 1930, the term adenoid cystic carcinoma was suggested by Spies (4). Adenoid cystic carcinoma more often occur in the salivary glands, however also less frequently encountered in larynx

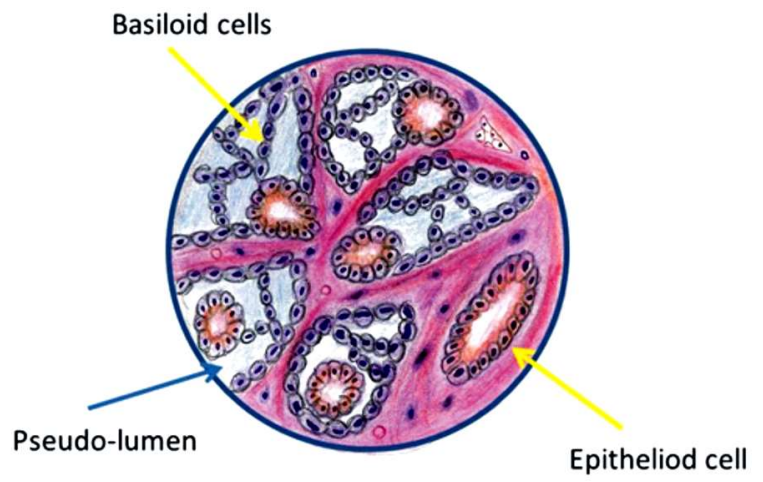

Figure 1. ACC dual population of epitheloid and baseloid cells. True glandular lumina composed of cuboidal cells showing ductal differentiation The pseudolumen contain basophilic glycosaminoglycans and/or eosinophilic, periodic acid-Schiff-positive basal lamina material (by Abdalla Saad Abdalla Al-Zawi)
(5), bronchi (6) and breast $(7,6)$. It is a low ${ }^{-}$ grade tumour with favourable prognosis, and hardly metastasize to the axillary lymph node or distant organs $(7,8)$. BACC is more common in female of the age group between 50-60 years of age (9).

It is known to be a triple negative cancer expressing neither female sex hormone receptors nor human epidermal growth facror-2 (HER2-neu). Most breast cancers with triple-negative, basal-like breast features (i.e., tumours that are not expressing oestrogen receptor, progesterone receptor, and human epidermal growth factor receptor-2 (Her2), however express basal cell markers) are generally high-grade aggressive tumours. On the contrary, although BACC also exhibits a triple-negative, however the genetic expression showed that, they are different from basal-like phenotype (10). This may explain why they are usually of low-grade malignancy and display an indolent clinical behaviour (3, 8,11). Principally, BACC prognosis is better than the one for salivary gland and also than that of other breast invasive carcinoma.

\section{Case Report}

A female aged 73 years, presented with a right breast lump, eight years earlier treated for contralateral breast DCIS (Fig. 2). The mammogram (Fig. 3, A) and breast ultrasound (Fig. 5) showed indeterminate $22 \mathrm{~mm}$ lump, the core biopsy revealed a tumour comprised of proliferation of bland like epithelial cells, forming cribriform architecture, within a background of collagenous stroma. The provisional diagnosis was possible benign 

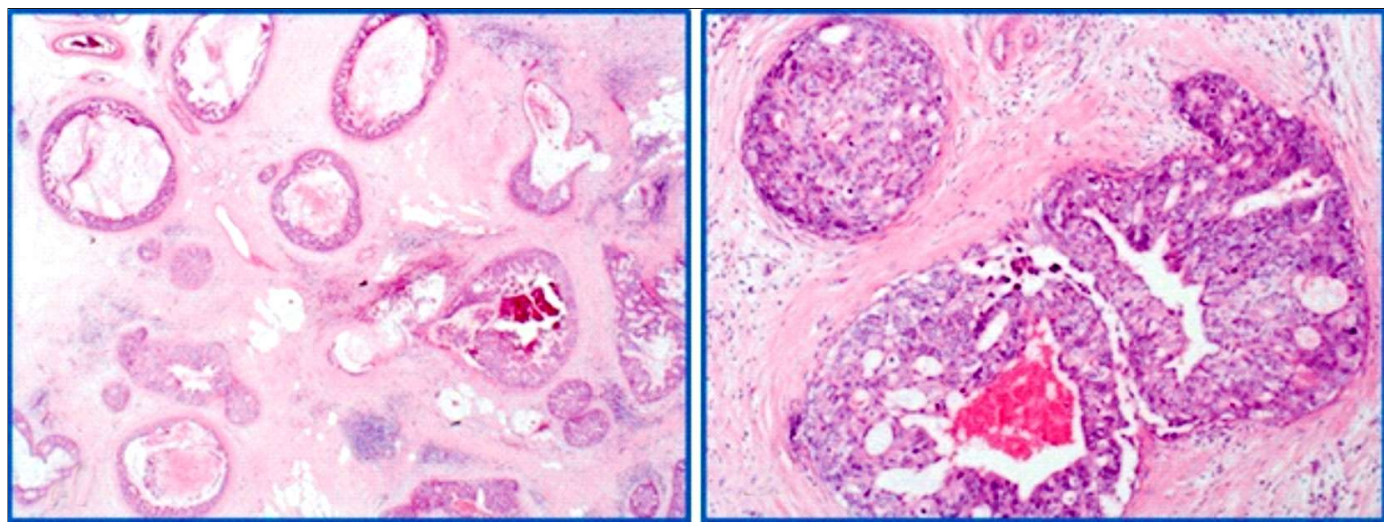

Figure 2. DCIS left breast (A) x2,(B) x10: Section shows ductal carcinoma-in-situ composed of solid and cribriform pattern. Foci with comedo-necrosis and microcalcification are present
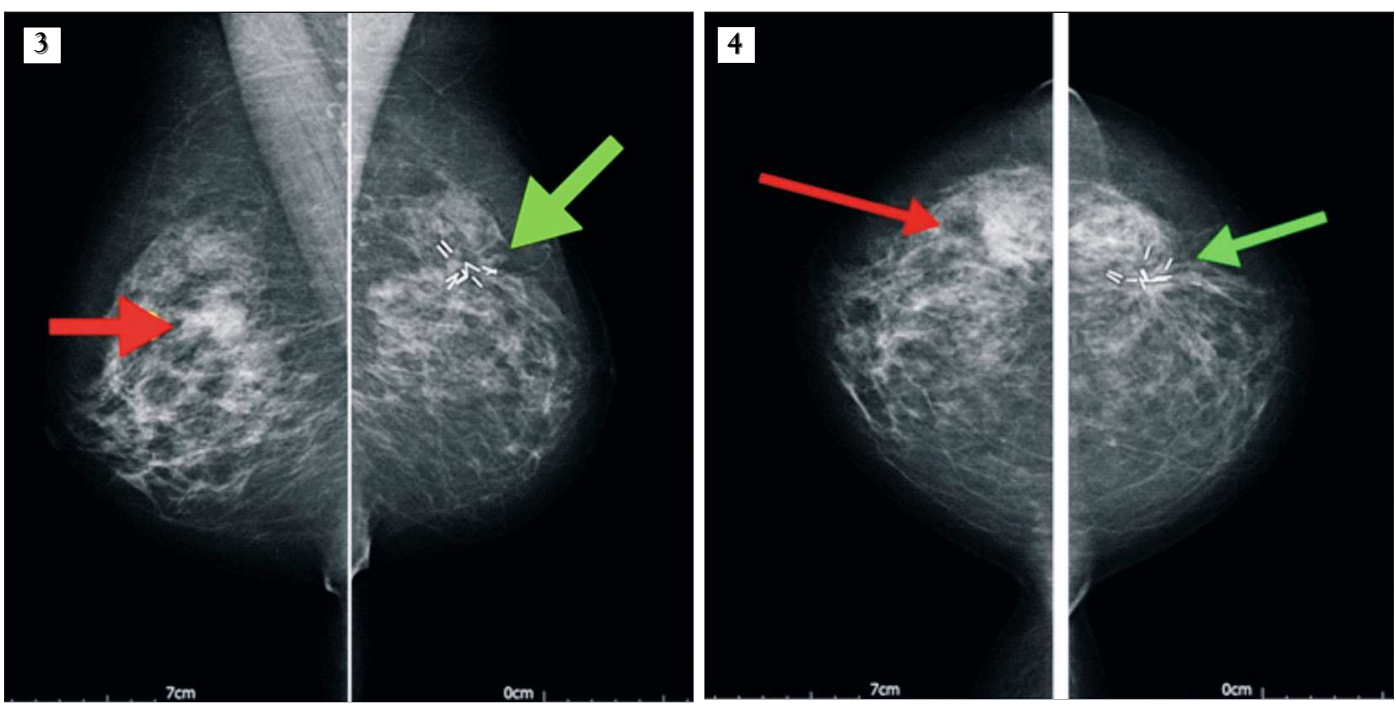

Figures 3, 4. Mammogram MLO and CC views shows indeterminate lesion in the upper outer quadrant right breast (red arrow).The left breast shows marking clips from previous lumpectomy for DCIS (green arrow). Keys: Long arrow - Microcalcification. Short arrow - necrotic material in comedo necrosis

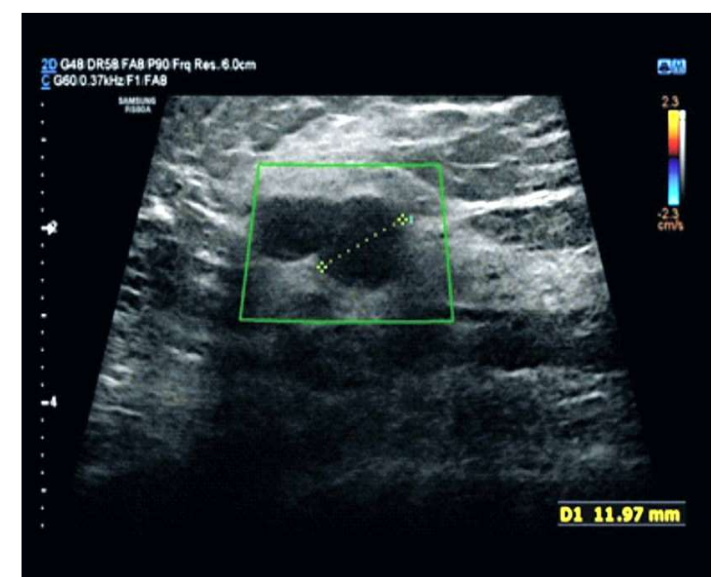

Figure 5. Breast ultrasonography shows $22 \mathrm{~mm}$ indeterminate lesion in the upper outer quadrant right breast myo-epithelial tumour. The multi-disciplinary team advised for lumpectomy due to suspicious radiological features. Wire guided excision biopsy perfumed (Fig. 6), this showed $22 \mathrm{~mm}$ tumour adenoid cystic carcinoma, without features of lympho-vascular invasion and was completely excised (Fig. 7 ). The tumour shows a biphasic staining pattern, the one comprising epithelial cells expresses patchy but strong positivity for AE1/AE3 (Fig. 8), HMWCK/34 beta $\mathrm{E} 12$ (Fig. 9), $\mathrm{CD} 117$ (Fig. 10), $\operatorname{EMA}$ (Fig. 11) \& CK7, in the myoepithelial cells the patchy strong positivity seen in p63 (Fig. 12), S100 (Fig. 13), CD10 (Fig. 14) \& SMA (Fig. 15). The tumour cells were negative for Cam5.2, oestro- 


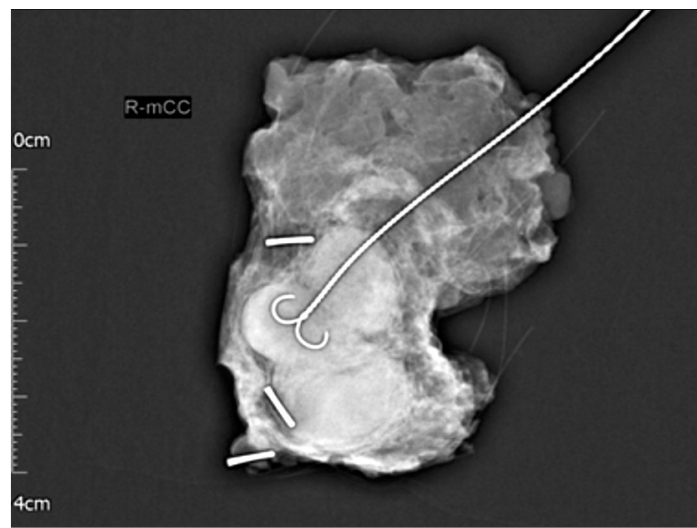

Figure 6. Lumpogram of the excised lump

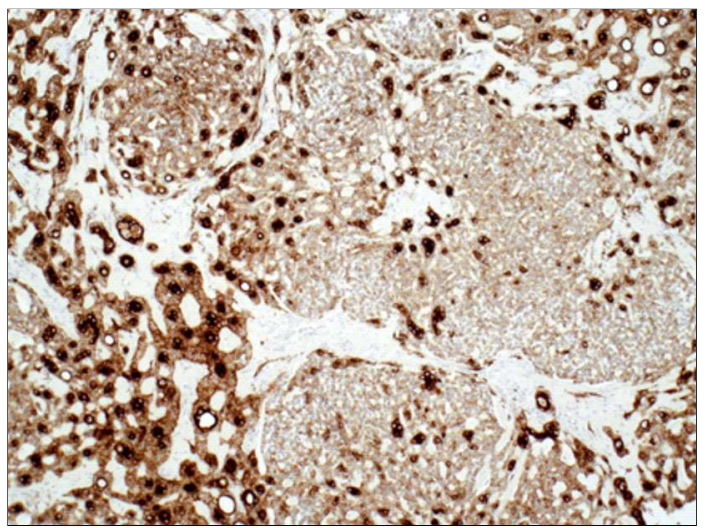

Figure 8. EA1/EA3 patchy but strong positivity pan cytokeratin marker

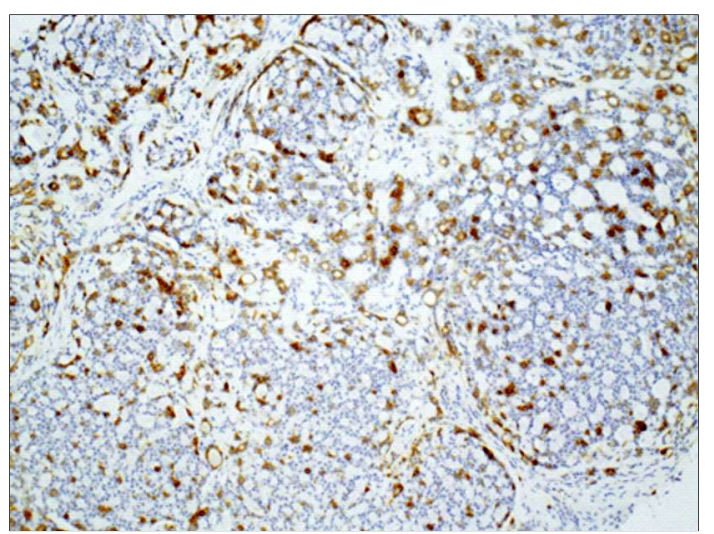

Figure 10. CD117 patchy but strong positivity

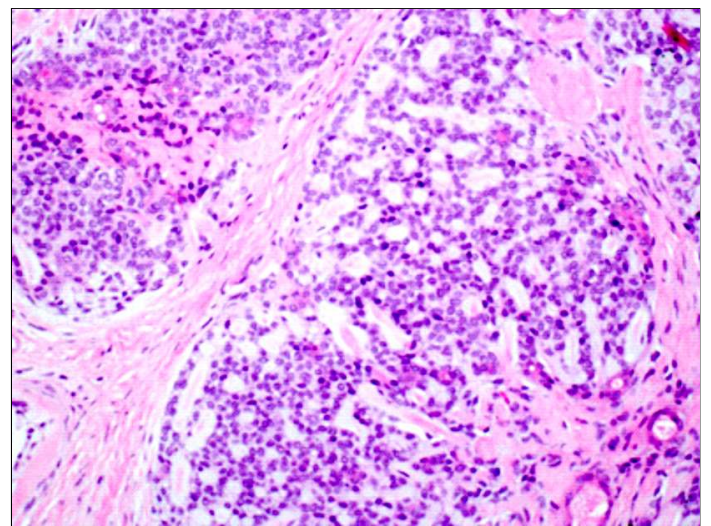

Figure 7. Breast tissue infiltrated by adenocystic carcinoma comprising cribriform and tubular glands (20x H\&E)

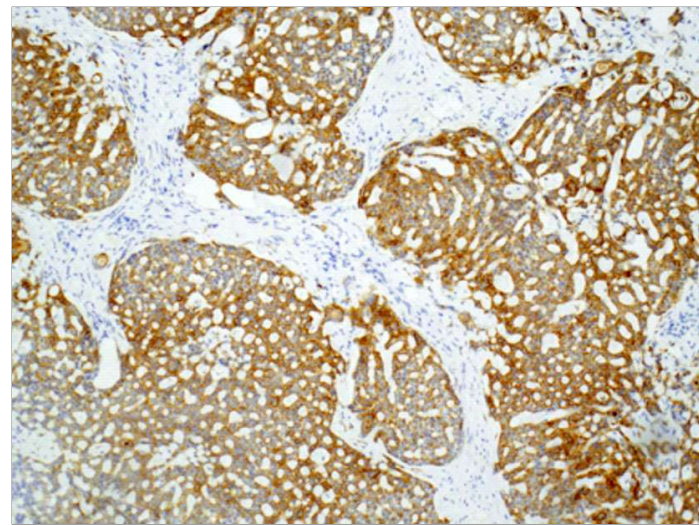

Figure 9. HMWCK/34betaE12 patchy but strong positivity

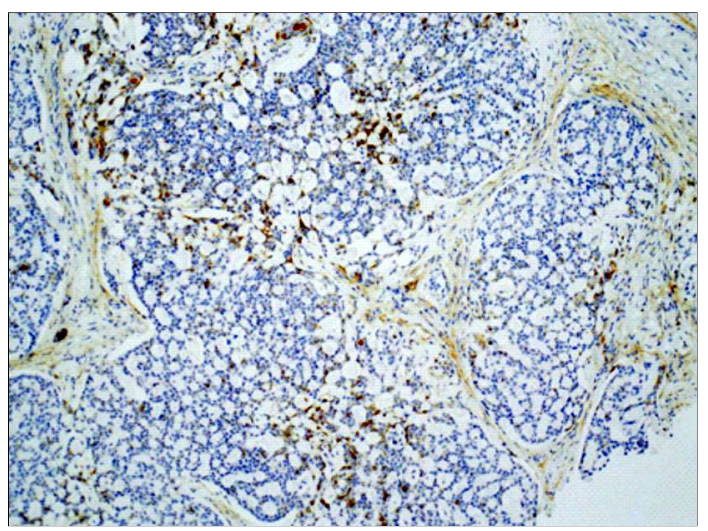

Figure 11. EMA patchy positivity

three lymph nodes retrieved. Both frozen section and paraffin section showed no axillary lymph node metastasis. Also further excision of the tumour cavity margins performed to ensure gen receptors $0 / 8$, progesterone receptors $0 / 8$ and Her-2 receptors (score 0) where Ki67 was $2 \%$. Accordingly, radio-colloid and blue dye assisted sentinel lymph node biopsy done and 


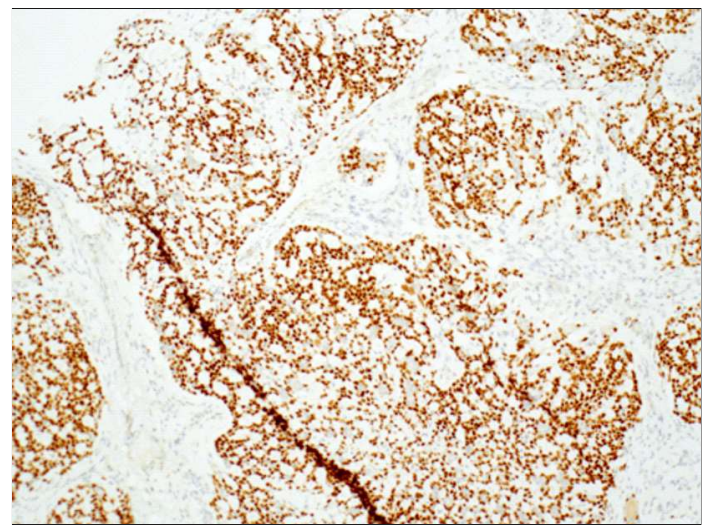

Figure 12. p63, strong patchy positivity

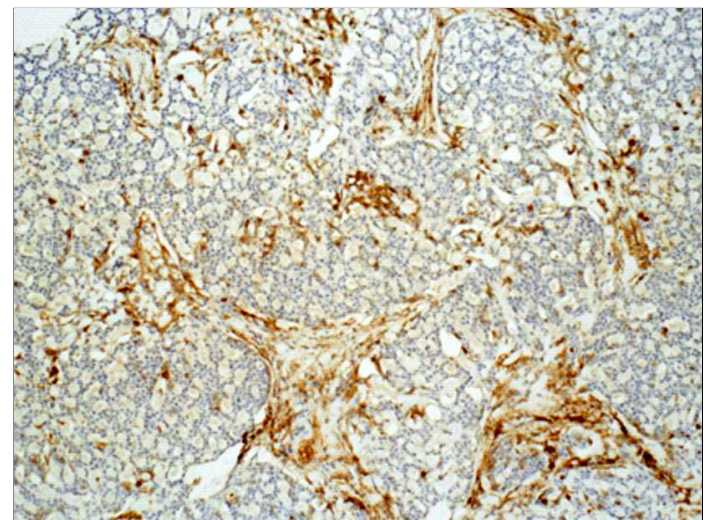

Figure 14. CD10 patchy positivity

a complete tumour excision, no residual disease detected. The post-operative period was uneventful. The patient had staging CT chest and abdomen, no distant metastatic disease has been detected. As the most recent reports mention that, breast conservation surgery with adjuvant radiotherapy is associated with a low recurrence rate, the patient has been referred for adjuvant radiotherapy. This has been completed and the patient currently under a yearly surveillance mammogram.

\section{Discussion}

In the year 2012, World Health Organization classification, highlighted that invasive ductal carcinoma of no special type (NST) is the most common histologic type of primary invasive breast cancers (accounting for up to 75\%) (1). Adenoid cystic carcinoma which is commonly

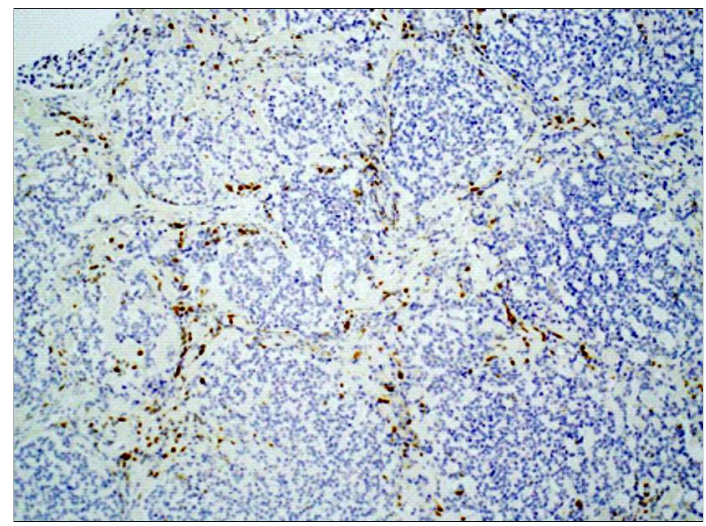

Figure 13. S100 patchy positivity

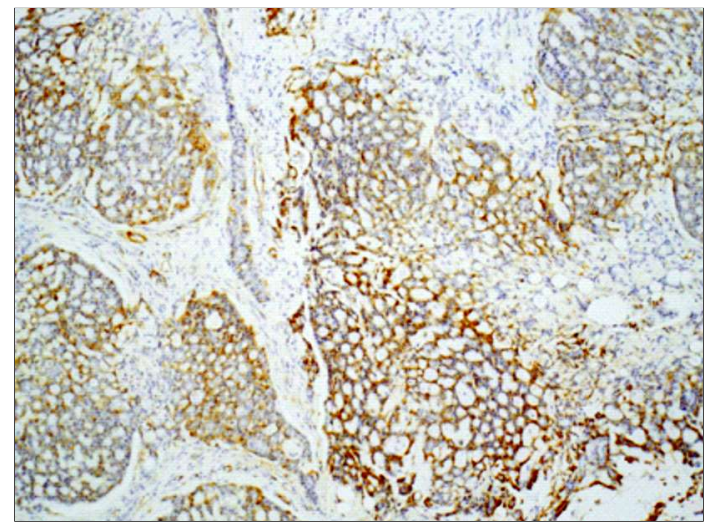

Figure 15. SMA patchy positivity

seen in the salivary gland, is less frequent in the breast $(7,6)$, larynx $(5)$, bronchi $(6,12)$, lung (13), oesophagus (14), cervix (15,16), Bartholin's gland (17) lacrimal glands (18), skin (19) and prostate (20). Although it has been encountered in young ladies with age of 19 as well as older age up to 97 years of age in addition to the paediatric age group (21), BACC is more common in female of the postmenopausal middle age group between the fifth and sixth decade (22-24). This tumour is not restricted to female gender, as it has reported in men also (25), it is representing less than $0.1 \%$ of all detected breast cancers $(1,3)$. BACC characteristic patho-morphological pattern includes unique dual cellular population of both luminal epithelial and basal myoepithelial components which are seen also in adenoid cystic carcinoma of the salivary gland, however BACC prognosis is better than 
the one for salivary gland $(8,26)$. Despite the fact that the perineural invasion is not uncommon in BACC, the pain symptom of the adenoid cystic carcinoma in general is attributed to the tumour perineural invasion (27). Most common presenting symptoms are well-circumscribed palpable painful lump located in the peri-areolar area and outer quadrants of the breast $(7,22,24)$. Less frequent symptoms are nipple inversion, blood nipple discharge and skin retraction, also may be detected as an incidental finding during screening or during imaging for unrelated symptoms $(9,24)$.

The researches stated that these tumours arise from the breast ductal epithelium or the myoepithelium (9), microscopically, the tumour is characterised by dual-cellular population, one is true luminal epithelial cells and the other is myoepithelial-basal cells (Fig. 1). The tumour cells may be arranged in tubular-trabecular, cribriform, or solid-basaloid pattern (1). The epithelial luminal cells are of cuboidal variety with round nuclei and eosinophilic cytoplasm, will form a true glandular spaces, the lumina are filled with periodic acid-Schiff-positive neutral mucin. The second cellular population is formed of myoepithelial-like cells, they will form the lining of the pseudo-luminal or cribriform spaces. These spaces are filled with basement membrane-like materials as myxoid or mucinous proteins (Fig. 1), (24). BACC had more grade 1 tumors than invasive ductal carcinoma (46 vs. $18 \%$ ) as well as has had fewer oestrogen receptor positive expression as well as fewer progesterone receptor-positive expression, $(15.4$ vs. $75.6 \%)$ and (13.3 vs. $65.2 \%)$ respectively (23).

It is well known that patients with triple negative breast cancer has more BRCA1 mutation than BRCA2, also triple negative breast cancer is less common in BRCA mutation non-carriers. Among the newly diagnosed invasive breast cancer cases, about $10 \%$ have either BRCA1 or BRCA2 mutations, also about $20 \%$ will present with a triple negative disease and one third of BRCA1 cases will develop breast cancer (28). Despite BACC is a triple negative breast cancer, no correlation was detected between BACC and the existence of BRCA1 and BRCA2 gene mutation (22). Genetic mutation of P53 has been reported to be associated, however it is not clearly defined (29).

Metastasis to axillary lymph nodes is extremely rare and not exceeding 2\% (7). Despite that, BACC has been diagnosed in the presence of invasive ductal carcinoma of no special type in the same breast, that harbors adenoid cystic carcinoma, it is seldom to exhibit a presence of a different type of invasive breast neoplasm in a breast that contain BACC. This phenomena is another important bio-criteria associated with BACC (30). Breast adenoid cystic carcinomas can pose preoperative diagnostic challenge to the clinician due to the disease rarity, and especially in presence of limited biopsy tissue material as in our case. Immuno-histochemical markers plays an important role in BACC diagnosis, in addition to absence of oestrogen, progesterone and Her2- receptors expression, smooth muscle actin is antibody protein to alpha smooth muscle actin, it is useful to identify myoepithelial cells in normal and neoplastic breast tissue (31,32). S100 is low-molecular protein usually positive in melanoma and also useful in myoepithelial differentiation $(33,32)$, it was positive in our case. AE1/AE3 protein, known as keratin cocktail (for CK1 -8, 10, 14 16 and 19 detection) is useful marker to stain the epithelial cells as in adenoid cystic carcinoma and melanoma $(34,35)$. CD117, or c-KIT, is a receptor tyrosine kinase protein which is encoded by KIT, it shows positivity in gastrointestinal stromal tumour (GIST) (36) as well as in the epitheloid component of the adenoid cystic carcinomas in different primary sites including breast (37), it was positive in our case.

CK7 (Cytokeratin 7), which is type II keratin used to stain simple non-keratinizing epithelia, it was positive in the epitheloid cells of the case (38). CK5/6 is a cytokeratin marker used to identify breast basal/myoepithelial cells and it expresses positivity in BACC $(39,40)$.

The myoepithelial marker $\mathrm{p} 63$ which rarely 
stains the adenocarcinomas, was positive in the myoepithelial component of the tumour (38). IMP3 (Insulin-like growth factor-mRNAbinding protein 3 ) is an oncofetal protein and is an element of insulin-like growth factor pathway, the recent researches revealed that IMP3 can serve as basal-like breast carcinomas bio-marker, as it is commonly exhibits overexpression in BACC (41). SOX10 is a protein marker usually shows positive nuclear staining in basal-like unclassified triple negative breast cancer (42). SOX10 is regarded as a sensitive diagnostic marker in the adenoid cystic carcinomas, this might potentially aid in diagnosis of this neoplasm on limited biopsy material (43). The basic type II keratin, Cytokeratin 7(CK7) which is a protein found in simple non-keratinising epithelial cells of the breast, gut, lungs and endometrium (44). CK7 was positive in our case.

It has been reported that overexpression of MYP protein and its related gene is a key element in BACC pathogenesis. MYP gene located in chromosome 9, it fuses with another gene called NFIB(Nuclear Factor I B) which located in chromosome 6 forming $\mathrm{t}(6 ; 9)$ (q22-23;p23-24) fusion gene, this gene combination believed to be linked to breast adenoid cystic carcinoma oncogenesis $(45,46)$.

The differential diagnosis of BACC include cribriform carcinoma (Table 1), collagenous spherulosis (Table 2), small cell carcinoma (neuroendocrine carcinoma), solid papillary carcinoma, metaplastic carcinoma, and malignant lymphoma (11). BACC remote metastases are not common, and they have a tendency to occur in presence or absence of regional lymph nodes invasion. The most frequent metastatic site is the lung, this followed by liver, bones and kidney. The sites are also typically harbours the metastatic disease from the salivary glands adenoid cystic carcinoma $(7,2)$. Current practised treatment is concentrated on radical surgical, either breast conservation surgery or mastectomy (simple or modified radical), however there are no particular guidance for the resection margin range. Mastectomy was the

Table 1. Cribriform carcinoma as a differential diagnosis to BACC $(11,24,37,39)$

\begin{tabular}{lll}
\hline & Adenoid cystic carcinoma & Cribriform/tubular carcinoma \\
\hline Periodic Acid-Schiff & Positive in basement membrane & No basement membrane stain \\
\hline Cellular population & Dual & Single \\
\hline Myoepithelial component & Present & Absent \\
\hline Ckit & Positive & Negative \\
\hline Oestrogen Receptor (ER) & Negative & Positive \\
\hline Progesterone (PR) & Negative & Positive \\
\hline Her-2 & Negative & Positive \\
\hline DCIS & Absent & Present \\
\hline p53 & Positive & Negative \\
\hline
\end{tabular}

Table 2. Collagenous spherulosis as a differential diagnosis to $\operatorname{BACC}(11,37,39)$

\begin{tabular}{lll}
\hline & Adenoid Cystic Carcinoma & Collagenous spherulosis \\
\hline Presentation & Palpable breast lesion & Incidental microscopic finding \\
\hline Architecture & Invasive carcinoma & Circumscribed, intra-ductal or intra-lobular \\
\hline Basement membrane (BM) & Uniform cores of BM & Variable, frequently fibrillar spherules \\
\hline Mucin & Present & Absent \\
\hline Nuclei & Slightly enlarged & Identical and normal \\
\hline CD117 & Positive & Negative \\
\hline Calponin & Negative & Positive \\
\hline Smooth muscle myosin & Negative & Positive \\
\hline
\end{tabular}


most described surgical technique for BAAC, purely because it is used frequently to treat the common breast cancers subtypes and is associated with a low local recurrence rate $(8,21,26)$. Cotaes et al in 2010 , analysed the role of adjuvant radiotherapy after surgical excision of BACC, the cohort group formed of 376 patients and the outcome showed that adjuvant post-operative radiotherapy improved both cause specific and overall survival with benefit of $21 \%$ and $7 \%$ at 10 years $(\mathrm{P}=0.005$ and $\mathrm{P}=0.12$ respectively). This was based on SEER (Surveillance, Epidemiology, and End Results) database studies and it concluded that postoperative adjuvant radiotherapy after breast conservation surgery in BACC, improved both overall survival and diseasespecific survival rates (47). The most recent reports, emphasize that breast conservation surgery combined with adjuvant radiotherapy to the breast has a low local recurrence rate (26). Regarding the axillary surgery, as mentioned above, BACC metastasis to axillary lymph nodes is extremely rare and not exceeding $2 \%$ (7), most of the authors recommend to avoid axillary nodes as it does not have a beneficial role in the BACC management (8). Chemotherapy has a limited space, however may be indicated for distant metastatic disease (7). Generally speaking, the triple negative breast cancer (TNBC) is associated with poor prognosis, the overall five years survival is $91 \%$, where it is only $65 \%$ for the node positive TNBC and just $11 \%$ for patient with distant metastatic disease (48).

However the 10-year overall survival rate for BACC patients is ranging from $85 \%$ to $100 \%$.Breast cancer treatment now enters a new stage with the introduction of targeted therapies, the merged MYB-NFIB fusion gene trials may come up with new therapeutic options for the advanced BACC management (24). Vranic et al in 2010 presented a case series and reported that BACC frequently over-express epidermal growth factor receptors (EGFR). This has exposed the presence of a potential benefit from using epidermal growth factor receptor blockade therapy for cases with advanced breast adenoid cystic carcinoma (33).

\section{Conclusion}

BACC is a rare subtype of breast cancer, it has clinico-pathomorphological characteristics that set it apart from the other triple negative breast cancers. Additional clinical research is required in order to implement BACC optimal individualized and tailored management guidelines.

\section{Authors' Contribution}

All the authors contributed to paper drafting and revising it critically for important intellectual content; and they gave the final approval of the version to be submitted and any revised version.

\section{Conflict of interest}

All author declare that they have no conflict of interest.

\section{References}

1. Lakhani SR, Ellis LO, Schnitt SJ, Tan PH, van de Vijver MJ. World Health Organization Classification of tumours of the breast, $4^{\text {th }}$ ed. Lyon: IARC Press, 2012.

2. Kocaay AF, Celik1 SU, Hesimov I,Eker T, Percinel S, Demirer S. Adenoid Cystic Carcinoma of the Breast: A Clinical Case Report. Med Arch. 2016;70(5):392-394.

3. Mhamdi HA, Kourie HR, Jungels C, Aftimos P, Belbaraka R, PiccartGebhart M. Adenoid cystic carcinoma of the breast - an aggressive presentation with pulmonary, kidney, and brain metastases: a case report. J Med Case Rep. 2017; 11(1):303.

4. Andreasen S. Molecular features of adenoid cystic carcinoma with an emphasis on microRNA expression. PhD Thesis.APMIS.2018; 126:S240.

5. Cui Y, Bi L, Sun L, Wang X, Zhu Z. Laryngeal adenoid cystic carcinoma: Three cases reports. Medicine (Baltimore). 2019; 98(51):e18177.

6. Kashiwagi S, Asano Y, Ishihara S, Morisaki T, Takashima T, Tanaka S, et al. Adenoid Cystic Carcinoma of the Breast: A Case Report. Case Rep Oncol. 2019;12(3):698-703.

7. Kim M, Lee DW, Im J, Suh KJ, Keam B, Moon HG et al. Adenoid cystic carcinoma of the breast: a case series of six patients and literature review. Cancer Res Treat. 2014;46(1):93-7.

8. Thomas DN, Asarian A, Xiao P. Adenoid cystic carcinoma of the breast. Journal of Surgical Case Reports, 2019;1:1-3.

9. Junainah E, Baslaim M, Shegairi S, Mashhoor R, Alsalmi T, Bajaber $A$, et al. Adenoid cystic carcinoma of the breast, high grade with basal phenotype, literature review. International Journal of Surgery Open.2018;10:43e46

10. Rakha EA, Elsheikh SE, Aleskandarany MA, Habashi HO, Green AR, 
Powe DG, et al. Triple-negative breast cancer: distinguishing between basal and nonbasal subtypes. Clin Cancer Res. 2009; 15(7):2302-10.

11. Miyai K, Schwartz MR, Divatia MK, Anton RC, Park YW, Ayala AG, et al. Adenoid cystic carcinoma of breast: Recent advances. World J Clin Cases. 2014;2(12):732-741.

12. Masih I, Porter G, Porter S, Clarke R, Sidhu P, Harney J, et al. Primary adenoid cystic carcinoma of the bronchus in a female teenager. BMJ Case Rep. 2010;2010:bcr0820103252.

13. Saha $\mathrm{K}$, Jash $\mathrm{K}$ et al. Adenoid Cystic Carcinoma of the Lung with Bilateral Renal Metastases at Presentation in a Young Female. Middle East Journal of Cancer 2011;2(3 \& 4):129-133

14. Sawada G, Moon J, Saito A, Odagiri K, Kimura Y, Takahashi G, et al. A case of adenoid cystic carcinoma of the esophagus. Surg Case Rep. 2015;1(1):119.

15. Benhayoune K, El Fatemi H, Bannani A, Melhouf A, Harmouch T. Adenoid cystic carcinoma of cervix: two cases report and review of the literature. Pan Afr Med J. 2015; 20:77.

16. Sinaa M, Oukabli M, Albouzidi A. Adenoid cystic carcinoma of cervix in younger women: report of two new cases. Pan Afr Med J. 2014; $19: 99$.

17. Johnson LR, Nair RP, Sambasivan S, Mony RP, Gangadharan J, Kumar A, et al. Adenoid cystic carcinoma of vulva- 11 years' singleinstitution experience. J Obstet Gynaecol India. 2017;67(3): 196-201.

18. Yang J, Zhou C, Wang Y, Fan X, Jia R. Multimodal therapy in the management of lacrimal gland adenoid cystic carcinoma. BMC Ophthalmol. 2019;19(1):125.

19. Tonev ID, Pirgova YS, Conev NV. Primary Adenoid cystic carcinoma of the skin with multiple local recurrences. Case Rep Oncol. 2015; 8(2):251-255.

20. Iczkowski KA, Montironi R. Adenoid cystic/basal cell carcinoma of the prostate strongly expresses HER-2/neu. J Clin Pathol. 2006; 59(12):1327-1330.

21. Boujelbene N, Khabir A, Boujelbene N, Jeanneret Sozzi W, Mirimanoff R0, Khanfir K. Clinical review - breast adenoid cystic carcinoma. Breast. 2012;21(2):124-127.

22. Olszewska M, Głuszek S. Adenoid cystic carcinoma of the breast. Medical Studies/Studia Medyczne 2017;33(4):304-307.

23. Kulkarni N, Pezzi CM, Greif JM, Klimberg VS, Bailey L, Korourian S, et al. Rare breast cancer: 933 adenoid cystic carcinomas from the National Cancer Data Base. Ann Surg Oncol. 2013:20(7):2236-41.

24. Bhutani N, Kajal P, Singla S. Adenoid cystic carcinoma of the breast: Experience at a tertiary care centre of Northern India. Int J Surg Case Rep. 2018;51:204-209

25. Hjorth S, Magnusson PH, Blomquist P. Adenoid cystic carcinoma of the breast. Report of a case in a male and review of the literature. Acta Chir Scand. 1977;143(3):155-8.

26. Arpino G, Clark GM, Mohsin S, Bardou VJ, Elledge RM. Adenoid cystic carcinoma of the breast: molecular markers, treatment, and clinical outcome. Cancer 2002:94:2119-2127

27. Law YM, Quek ST, Tan PH, Wong SLJ. Adenoid cystic carcinoma of the breast. Singapore Med J. 2009;50(1):e8-11.

28. Peshkin BN, Alabek ML, Isaacs C. BRCA1/2 mutations and triple negative breast cancers. Breast Dis. 2010;32(1-2):25-33.

29. Yamamoto $\mathrm{Y}$, Wistuba LI, Kishimoto $\mathrm{Y}$, Virmani AK, Vuitch F, Albores-Saavedra J, et al. DNA analysis at p53 locus in adenoid cystic carcinoma: Comparison of molecular study and p53 immunostaining. Pathol Int. 1998;48(4):273-80.

30. Righi A, Lenzi M, Morandi L, Flamminio F, De Biase D, Farnedi A, et al. Adenoid cystic carcinoma of the breast associated with invasive duct carcinoma: a case report. Int J Surg Pathol 2011;19:230-234.

31. Zhang RR, Man YG, Vang R, et al. A subset of morphologically distinct mammary myoepithelial cells lacks corresponding immunophenotypic markers. Breast Cancer Res. 2003;5(5): R151-R156.

32. Sato S, Kijima H, Suto A, Yoshida H, Sato T, Shimbori M, et al. Fineneedle aspiration cytology of breast lesions: a review of cytological analysis using smooth muscle actin (SMA) immunostaining. Anticancer Res. 2003;23(5b):4175-9.

33. Saad Abdalla Al-Zawi A, Prodromou A, Chicken W, Comez T, Deniz E. Merkel cell carcinoma: literature review. NOWOTWORY J Oncol 2017;67(2):127-31.

34. Gokaslan ST, Carlile B, Dudak M, Albores-Saavedra J. Solitary cylindroma (dermal analog tumor) of the breast: a previously undescribed neoplasm at this site. Am J Surg Pathol. 2001;25(6):823-826.

35. Nagano CP, Coutinho-Camillo CM, Pinto CA, Soares FA, Santos F, Fonseca $\mathrm{I}$, et al. Cytokeratin immunoprofile of primary and metastatic adenoid cystic carcinoma of salivary glands: a report of two cases. Autops Case Rep. 2016;6(4):57-63.

36. Yantiss RK, Spiro IJ, Compton CC, Rosenberg AE. Gastrointestinal stromal tumour versus intra-abdominal fibromatosis of the bowel wall: a clinically important differential diagnosis. Am J Surg Pathol. 2000;24(7):947-957.

37. Crisi GM, Marconi SA, Makari-Judson G, Goulart RA. Expression of c-kit in adenoid cystic carcinoma of the breast. Am J Clin Pathol. 2005; 124(5):733-39

38. Ramaekers F, Huysmans A, Schaart G, Moesker 0, Vooijs P. Tissue distribution of keratin 7 as monitored by a monoclonal antibody. Exp Cell Res. 1987;170(1):235-249.

39. Stanford Medicine Surgical Pathology Criteria. http://surgpathcriteria. stanford.edu/breast/adcystcabr/differentialdiagnosis.html, visited on line on: 22 March 2020

40. Saad Abdalla Al-Zawi A, Memon S, Shah A, Eldruki S, Tan E, Alowami SO. A squamous cell carcinoma arising from scrotal epidermal cyst. A case report and review of 94 cases from the world literature. NOWOTWORY J Oncol 2019;69(3-4):150-6.

41. Vranic S, Gurjeva 0, Frkovic-Grazio S, Palazzo J, Tawfik 0, Gatalica Z. IMP3, a proposed novel basal phenotype marker, is commonly overexpressed inadenoid cystic carcinomas but not in apocrine carcinomas of the breast, Appl.Immunohistochem. Mol. Morphol. 2011;19:413-416.

42. Cimino-Mathews A, Subhawong AP, Elwood H, Warzecha HN, Sharma R, Park BH, et al. Neural crest transcription factor Sox 10 is preferentially expressed in triple-negative and metaplastic breast carcinomas. Hum Pathol. 2013;44(6):959-65.

43. Yang C, Zhang L, Sanati S. SOX10 Is a Sensitive Marker for Breast and Salivary Gland Adenoid Cystic Carcinoma: Immunohistochemical Characterization of Adenoid Cystic Carcinomas. Breast Cancer (Auckl). 2019; 13:1178223419842185. Published 2019 May 3. doi:10.1177/1178223419842185

44. Tot T. Patterns of distribution of cytokeratins 20 and 7 in special types of invasive breast carcinoma: a study of 123 cases. Ann Diagn Pathol. 1999;3(6):350-356.

45. Persson M, Andrén Y, Mark J, Horlings HM, Persson F, Stenman G. Recurrent fusion of MYB and NFIB transcription factor genes in carcinomas ofthe breast and head and neck. Proc. Natl. Acad. Sci. 2009:106:18740-44.

46. Wetterskog D, Lopez-Garcia MA, Lambros MB, A'Hern R, Geyer FC, Milanezi $F$, et al. Adenoid cystic carcinomas constitute a genomically distinct subgroup of triple-negative and basal-like breast cancers. J Pathol. 2012;226(1):84-96.

47. Coates JM, Martinez SR, Bold RJ, Chen SL. Adjuvant radiation therapy is associated with improved survival for adenoid cystic carcinoma of the breast. J Surg Oncol. 2010;102(4):342-347.

48. Webmed. Triple Negative Breast Cancer. https://www.webmd.com/ breast-cancer/triple-negative-breast-cancer 